\title{
ON THE HYERS-ULAM-RASSIAS STABILITY PROBLEM FOR APPROXIMATELY $k$-ADDITIVE MAPPINGS AND FUNCTIONAL INEQUALITIES
}

\author{
KIL-WOUNG JUN AND HARK-MAHN KIM
}

\begin{abstract}
The purpose of this paper is to solve the generalized Hyers-Ulam stability problem for a $k$-additive functional equation

$$
D_{m, i} f(x, y)=0,
$$
\end{abstract}

on the basis of direct method, where $k=4 m+i$ is a positive integer for each $i=-1,0,1$ and 2 .

Mathematics subject classification (2000): 39B82, 39B52.

Key words and phrases: $k$-additive mappings, generalized Hyers-Ulam stability, Banach modules.

\section{REFERENCES}

[1] J. ACZÉL, J. Dhombres, Functional Equations in Several Variables, Cambridge Univ. Press, 1989.

[2] M. AlberT, J. A. BAKER, Functions with bounded $n$th differences, Ann. Polon. Math., 43, (1983), 93-103.

[3] J. Chung, P. K. SAHOo, On the general solution of a quartic functional equation, Bull. Korean Math. Soc., 40, (2003), 565-576.

[4] P. CZERWIK, Functional Equations and Inequalities in Several Variables, World Scientific Publishing Company, New Jersey, Hong Kong, Singapore and London, 2002.

[5] D.Ž. Duoković, A representation theorem for $\left(X_{1}-1\right)\left(X_{2}-1\right) \cdots\left(X_{n}-1\right)$ and its applications, Ann. Polon. Math., 22, (1969), 189-198.

[6] M. FRÉCHET, Pri la funkcia equacio $f(x+y)=f(x)+f(y)$, Enseignement Math., 15, (1913), 390-393.

[7] Z. GAJDA, On stability of additive mappings, Internat. J. Math. Math. Sci., 14, (1991), 431-434.

[8] P. GǍVRUTA, A generalization of the Hyers-Ulam-Rassias Stability of approximately additive mappings, J. Math. Anal. Appl., 184, (1994), 431-436.

[9] H. HARUKI, TH. M. RASSIAS, A new functional equation of Pexider type related to the complex exponential function, Trans. Amer. Math. Soc., 347, (1995), 3111-3119.

[10] D. H. HYERS, On the stability of the linear functional equation, Proc. Natl. Acad. Sci., 27, (1941), 222-224.

[11] D. H. Hyers, Transformations with bounded $m$ th differences, Pacific J. Math., 11, (1961), 591-602.

[12] D. H. HYERS, G. ISAC AND TH. M. RASSIAS, "Stability of Functional Equations in Several Variables", Birkhłuser, Basel, 1998.

[13] D. H. HYERS, TH. M. RASSIAS, Approximate homomorphisms, Aequationes Math., 44, (1992), 125-153.

[14] K. Jun, Y. LEE, On the Hyers-Ulam-Rassias stability of a pexiderized quadratic inequality, Math. Ineq. Appl., 4, (1) (2001), 93-118.

[15] K. Jun, H. KIM, The generalized Hyers-Ulam-Rassias stability of a cubic functional equation, J. Math. Anal. Appl., 274, (2002), 867-878.

[16] K. JUN, H. KIM, Solution of Ulam stability problem for approximately biquadratic mappings and functional inequalities, Inequalities and Applications (edited by Th.M. Rassias), to appear.

[17] K. JUN, H. KIM, On the stability of an $n$-dimensional quadratic and additive functional equation, Math. Inequal. Appl., 9, (1) (2006), 153-165. 
[18] K. JUN, Y. LEE, A generalization of the Hyers-Ulam-Rassias stability of the Pexiderized quadratic equations, J. Math. Anal. Appl., 297, (2004), 70-86.

[19] S. Jung, Hyers-Ulam-Rassias Stability of Functional Equations in Mathematical analysis, Hadronic Press lnc., Palm Harbor, Florida, 2001.

[20] S. LEE, S. IM AND I. HwANG, Quartic functional equations, J. Math. Anal. Appl., 307, (2005), 387-394.

[21] S. MAZUR, W. ORLICZ, Grundlegende Eigenschaften der Polynomischen Operationen, Erst Mitteilung, Studia Math., 5, (1934), 50-68.

[22] J. M. RASSIAS, Solution of the Ulam stability problem for quartic mappings, Glasnik Matematički, 34, (1999), 243-252.

[23] TH. M. RAssias, On the stability of the linear mapping in Banach spaces, Proc. Amer. Math. Soc., 72, (1978), 297-300.

[24] TH. M. RASSIAS, P. ŠEMRL, On the behaviour of mappings which do not satisfy Hyers-Ulam stability, Proc. Amer. Math. Soc., 114, (1992), 989-993.

[25] TH. M. RASSIAS, On the stability of functional equations and a problem of Ulam, Acta Appl. Math., 62, (1) (2000), 23-130.

[26] TH. M. RASSIAS, On the stability of functional equations in Banach spaces, J. Math. Anal. Appl., 251, (2000), 264-284.

[27] T. TRIF, Hyers-Ulam-Rassias stability of a quadratic functional equation, Bull. Korean Math. Soc., 40, (2003), 253-267.

[28] S. M. Ulam, A Collection of Mathematical Problems, Interscience Publ., New York, 1960; Problems in Modern Mathematics, Chap. VI, Science ed. Wiley, New York, 1964. 